Mark Dennis, "Rethinking Premodern Japanese Buddhist Texts: A Case Study of Prince Shōtoku's Sangyō-gisho," Relegere: Studies in Religion and Reception I, no. I (2OII): I3-35.

This work is licensed under a Creative Commons Attribution Non-Commercial No Derivatives 3.0 License.

Relegere: Studies in Religion and Reception is an independent, open-access academic journal dedicated to the promotion and dissemination of innovative research in reception history, broadly conceived, within and across religious traditions.

Www.relegere.org

ISSN I I 79-723 I 


\title{
Mark Dennis
}

\section{Rethinking Premodern Japanese Buddhist Texts}

\section{A Case Study of Prince Shōtoku's Sangyō-gisho}

\begin{abstract}
This article examines the Sangyō-gisho 三経義疏 (Commentaries on the Three Sūtras), three Buddhist texts written in classical Chinese that have been attributed to Japan's Prince Shōtoku (574-622 CE). I will focus on the different ways in which four figures from the Kamakura era (I I $85-$ I $333 \mathrm{CE}$ ) understood, used, and valued these texts. Even among this small group of contemporary monks from the thirteenth century we will find distinct notions of what constitutes the "text," some of which differ in important ways from modern scholarly conceptions of the Sangyo-gisho. Through highlighting these different perspectives, I offer an alternative approach to a large body of modern scholarly studies, which has focused on a set of technical concerns looking back to the moment of the texts' composition.
\end{abstract}

\UCH MOdern scholarship on the Sangyō-gisho 三経義疏 (Commentaries on the Three Sūtras), ${ }^{1}$ three Buddhist texts written in classical Chinese that have been attributed to Japan's Prince Shōtoku (574-622), has

Mark Dennis is Assistant Professor of East Asian Religions at Texas Christian University.

${ }^{1}$ The Sangyō-gisho includes the I-fascicle Shömangyō-gisho 勝䰋経義疏 (Commentary on the Srimäalädevīsimhanäda-sütra; T2185.I-19), the 4-fascicle Hokke-gisho 法華義 
focused on recovering the "true record": principally whether or not Shōtoku wrote the texts, and what, if he did, he meant to say in them. In this kind of analysis, the "text" is taken as an unchanging body of ideas to which scholarly study can be applied to recover original meaning and value. This view naturally privileges the words of the text and accords considerable authority to those who have mastered established interpretive methods. This kind of analysis also marginalizes, or simply ignores, other "non-exegetical" forms in which the Sangyo-gisho have been used and valued by those who do not belong to interpretive communities, and among whom we can find a range of distinct relationships to Shōtoku and forms of authority for engaging his texts. Indeed, we will see that the techniques adopted by modern scholars represent a tradition of exegesis inherited from Gyōnen (I 240-I 32I), a Kamakura era scholar-monk of the Kegon school, whose intensive study of the individual texts did not appear until some six hundred years after Shōtoku's death. Until that time, only a few examples exist of scholar-monks who studied one or more of the three texts in any detail. Even so, the Sangyo-gisho were clearly valued as they were the subject of artwork and ritual, appeared in early versions of the canon, and were taken by Japanese monks to China in the eighth century as proof of the high level the nascent Buddhist tradition had attained.

In seeking to understand these alternative ways of engaging the Sangyogisho, we will draw upon the thought of Brian Stock who argues that we must "listen" for the text outside traditional exegesis since we rarely find an instance of a purely abstract text. That is, any text combines physical and mental attributes, possessing both "propositional content" and "procedural knowledge." 2 He writes, "One cannot assume that a text will reveal its meaning only through exegesis, for codified signs can also appear as types of text that are expressed in patterned behavior." ${ }^{3}$ Stock suggests, therefore, that a text's particular forms will be determined by conventional arrangements among the members of those communities that give it meaning and value, whether for interpretive functions (as we will see in the work of Gyōnen, the

疏 (Commentary on the Lotus-sütra; T2187.64-I28) and the 3-fascicle (in some accounts listed as 5-fascicles) Yuimagyō-gisho 維摩経義疏 (Commentary on the Vimalakirti-nirdeśa; T2 I 86.20-64). All three texts are also available on the SAT Daizōkyō Text Database website at: http://2 Idzk.l.u-tokyo.ac.jp/SAT/index_en.html.

${ }^{2}$ Brian Stock, Listening for the Text: On the Uses of the Past (Philadelphia: University of Pennsylvania Press, I990), I46.

${ }^{3}$ Ibid., 29. 
last figure we will look at), or for "causative" functions that are unrelated to the text's content. Although "causative" is a broad category, it is meant here to highlight a range of practices that are commonly found across Buddhist textual communities, but which have often been ignored in traditional forms of textual scholarship. In future work on the Sangyo-gisho I will hope to consider this wide range of practices in greater depth, looking, for example, at how each is associated with different sorts of communities capable of creating distinct notions of the texts' author, meaning, and value.

Here we will examine in broad strokes three figures who use the Sangyogisho causatively: Shinran (I I73-I 262) who poetically describes the texts' composition as a key historical event symbolizing the rise of the BuddhaDharma on the archipelago, and Kenshin (no dates) who used them as material objects to reinforce his own position within the monastic community and to secure financial benefits for his temple. Both figures were also involved in transmitting the significance of the texts' composition through artwork and other media. We will also consider Eison (I 20I-I290), who helped to produce artwork that depicts the Sangyo-gisho in front of Buddhist relics, and describes aspects of Shōtoku's exegesis in his autobiography, wasan 和讃, poetic hymns of praise, and kosshiki 講式, a textual genre written in the vernacular that often included some type of verbal performance. For these figures, therefore, the Sangyo-gisho did not exist solely as an abstracted body of ideas, nor were they "read" in a traditional sense. Indeed, these non-exegetical ways of engaging the Sangyo-gisho represent a long history of textual reception and use among Buddhist communities, but also a common pattern on the archipelago in the period immediately after the introduction of Chinese writing in the sixth century CE. To understand the Sangyo-gisho's place in the context of both the broader Buddhist textual traditions and early Japanese writing, we turn now to a discussion of Buddhist texts and a brief historical background of the earliest records of the Sangyo-gisho before offering our four specific examples of Kamakura figures.

\section{Buddhist Texts}

In the history of Buddhism, we find a wide range of ways in which texts are believed to have appeared in the world, where they can occupy both mental spaces and material forms. ${ }^{4}$ Although most were composed after intensive

${ }^{4}$ Early Buddhist texts were orally transmitted for hundreds of years before being committed to writing in the first century BCE. Even after written texts became common, oral transmission remained important. 
study using the traditional form of writing with black ink, some type of paper, and a brush or other writing instrument, this is not exclusively so. The gter ma, or "treasure texts," of Tibetan Buddhism are believed to have been hidden by the Indian monk Padmasambhava (eighth century), Yeshe Tsogyal (777-837), and others beneath a stone, in a cave, or even in the consciousness stream of a sentient being, only to manifest in the world at the proper time. $^{5}$ Indeed, the earliest Buddhist texts of Tibet are claimed to have fallen from the sky, while further to the east the Vajrasamädhi-sūtra 金剛三昧經 is said to have been discovered beneath the sea by an envoy from Silla, one of the early Korean kingdoms. ${ }^{6}$ There are Buddhist texts that have been written in the author's own blood, while others were brushed with golden ink on rare black or indigo papers. This is but one of many types of writing surfaces and instruments: among the former we also find birch bark, bamboo, stone, animal bone, metals, and cave walls.

And despite the tendency of modern scholars to view works like the Sangyo-gisho as mainly linguistic vehicles that transmit a fixed set of ideas, Buddhist texts have often been used causatively, generating varied types of thought, activity, and experience. Donald S. Lopez, Jr. reminds us that many Asian Buddhists were illiterate and that individual communities have often used texts for purposes with little if any relation to their content. ${ }^{7}$ Texts have been placed on altars and worshipped as material objects. Monks and nuns have sought to create good merit by copying texts like the Sangyo-gisho, while the laity have done so by having texts chanted in their homes by monastics. In some traditions, good merit could be generated by simply turning the pages of a Buddhist text and vocalizing, or just glancing at the words, suggesting that these texts could be meaningful and efficacious not only when read carefully from beginning to end.

While such practices condense the act of extracting meaning from a text, others abbreviate the text itself. A well-known example from East Asian Buddhist traditions is the Heart-sūtra 般若心經. 8 The Chinese text of this sūtra condenses into just 260 characters the central meaning of the Prajñāpāramitā

${ }^{5}$ For a discussion of the gter ma texts and their relation to religious authority and legitimacy, see, for example, Janet Gyatso, Apparitions of the Self: The Secret Autobiographies of a Tibetan Visionary (Princeton: Princeton University Press, 1998), I 45-8 I.

${ }^{6}$ See Robert E. Buswell Jr., The Formation of Ch'an Ideology in China and Korea: the Vajrasamädhi-sütra, A Buddhist Apocryphon (Princeton: Princeton University Press, 1989).

${ }^{7}$ See Donald S. Lopez Jr., The Story of Buddhism (New York: HarperOne, 2002).

${ }^{8}$ The Heart-sütra appears at T25 I. 
sūtras 大般若波羅蜜多經 (Perfection of Wisdom Sūtras), which are simultaneously located within a larger body of words, ideas, and texts_- Ioo,00o verses in the longest version - that one can read and study. The Heart-sütra is also noteworthy because it is not only commonly memorized, turning the mind itself into a sort of surface of inscription, but also because it is often read communally, being chanted, even now, daily in Zen temples.

A second example comes from Nichiren's (I 222-I 282) use of the Lotussūtra 法華經. Nichiren accords the Lotus-sūtra a central place in his teachings because he believed it to express the Buddha's ultimate Dharma, and so a single text symbolizes an entire teaching. Nichiren further taught his community to recite the daimoku 題目 (the simple mantra namu myōho renge-kyo 南無妙法蓮華經 “I pay homage to the wondrous law of the Lotus-sütra”), believing that these few words express the essence of the entire Lotus-sütra. The daimoku thus offers an example of an entire text condensed into a simple verbal formula that points at once beyond itself to the sūtra, to the highest teaching, and to the entire tradition, but also to a core salvific function.

While these examples illustrate language used to condense more expansive meaning, it has also been common for both literate and illiterate Buddhists to use texts and the material forms in which they have been inscribed for causative functions unrelated in any way to their content. In a discussion of Tibetan Buddhist texts, Damchö Diana Finnegan writes that books not only preserve texts but also generate experiences separate from their words and ideas as book handling practices among certain Tibetan Buddhist traditions are predicated on the value associated with a text's physical form. She argues that this

advice is presented not, as we might expect, by emphasizing the contents of those texts, but rather by focusing on the writings entirely as material objects. In fact, there is no suggestion whatsoever that the real essence of the book lies in its verbal meaning or content, rather than the material form in which it appears written. Indeed, since the treatment is recommended even for four syllables of teaching, clearly the value of such texts cannot be based in their ability to signify linguistically. ${ }^{9}$

${ }^{9}$ Damchö Diana Finnegan, Locating Meaning: The Written Text as a Physical Presence in the Tibetan Buddhist World, paper presented at the Annual Meeting of the American Academy of Religion, Toronto, November, 2002. 
In his work on the development of Japanese writing systems, David Lurie expresses similar ideas about Japanese texts more broadly, arguing that in the early stages of writing on the archipelago - which would include the Asuka period (538-710) in which Shōtoku lived-“an inscription that could be read was simply not necessary. The communicative function of the 'writing' on these artifacts, and by extension the writing on the imported artifacts that provided models for them, was not an element of their value." ${ }^{10}$ Texts in this period were used for a range of such "alegible" functions: creating magical patterns, forging diplomatic relationships, or exercising political power, and so even though unread, they were still "meaningful." ${ }^{11}$ Much like Stock, therefore, Lurie posits an important link between a text's range of potential functions and its value, arguing that to understand the latter requires us to sort through the relationship between legible and alegible uses.

\section{Early accounts of the Sangȳ̄-gisho}

As I suggested above, the Sangyo-gisho fit the pattern described by Lurie since they have been used for such alegible, or causative functions, and were clearly valued before they were widely interpreted. Indeed, the earliest accounts of Shōtoku's exegetical work are found in the period that Lurie examines, beginning with a small number of texts that include the Joggu Shötoku hōo teisetsu 上宮聖徳法王帝説, a Shōtoku biography whose author and dates of composition are unknown, and the Nihonshoki 日本書紀, an early Japanese "myth-historical" text compiled in 720 at the beginning of the Nara period (710-794).

The Nihonshoki was written in classical Chinese and modeled on the Chinese dynastic histories; it seeks to legitimize the Japanese imperial house by describing an unbroken lineage of sovereigns that begins with the Sun Goddess and is traced through a line of human sovereigns that includes Empress Suiko (554-628), Shōtoku's aunt. The text depicts Shōtoku as an adroit politician who, after being appointed regent by his aunt in 593, played a key role in the government. He is credited with composing a constitution (commonly known as the Seventeen Article Constitution 十七条憲法) and two historical texts (the Tennōki 天皇記 and the Kokki 国記), and with promoting diplomatic and religious contacts with China’s Tang and Sui dynasties as

${ }^{10}$ David Lurie, "The Origins of Writing in Early Japan: From the Ist to the 8th Century C.E.” (Ph.D. diss. Columbia University, 200I), го2.

${ }^{11}$ Ibid., 68. 
well as with the Korean kingdoms. Shōtoku is also credited with promoting the new Buddhist faith that had only recently arrived from one of those Korean kingdoms. Indeed, the prince is depicted as a generous patron and devout practitioner of the foreign faith, said to have built temples, including Hōryūji and Shitennōji, donated land to the Buddhist community, and collected Buddhist texts and invited masters from abroad. He is described as possessed of a keen intellect and deep understanding of the doctrines of the new faith, which he honed under the instruction of Hyeja, his Buddhist teacher from the Korean kingdom of Koguryŏ. These studies under Hyeja are thought to have led to lectures at court on the Srimālä-sütra and the Lotussütra and eventually to the composition of the three sūtra commentaries that make up the Sangyō-gisho. ${ }^{12}$

Although the Nihonshoki says nothing of Shōtoku's composition of the Sangyo-gisho, other texts of this era attribute the commentaries directly to Shōtoku, often describing the lectures as the basis for the compositions. Among these other texts is the Jōgu Shötoku hōo teisetsu which scholars believe to be roughly contemporaneous with the Nihonshoki. Like the Nihonshoki, the Teisetsu describes Shōtoku's studies with Hyeja and his rapid mastery of Buddhist teachings, but also notes his composition of the Hokke-gisho (his long Lotus-sütra commentary) and "other texts." ${ }^{13}$ Claims of Shōtoku's au-

\footnotetext{
${ }^{12}$ Some scholars believe that these accounts might have been influenced by Hōryūji monks who may have deliberately helped compilers forge a connection between Shōtoku's exegesis of the Lotus-suttra and an imperial gift of land to the temple from Empress Suiko. This connection, they argue, was established as a means to legitimize those land holdings and to raise the temple's status relative to other prominent Buddhist temples.

${ }^{13}$ The Teisetsu notes that during his tutelage under Hyeja, and at the behest of Empress Suiko, Shōtoku offered lectures on the Srimāalä-sütra to a number of dignitaries that lasted for three days. In contrast to the Nihonshoki, however, the Teisetsu places these lectures in the fourth month of 598 , some eight years before the date recorded in the Nihonshoki. The Teisetsu describes his lectures as being "like those of a monk" and notes that all in attendance were greatly pleased, gained faith, and converted to Buddhism. After these lectures, Empress Suiko offered Shōtoku a substantial gift of land in the Harima region, which he pledged, in turn, to Hōryūji. But the text does not mention Shōtoku's lectures on the Hokke-gisho, which are mentioned in the Nihonshoki, nor specifically his authorship of two of the three commentaries, stating instead: "[King Jōgū composed] commentaries on the Lotus-sütra and other sūtras totaling 7 -fascicles, which are known as 'the commentaries produced by [King] Jōgü'." Although the Teisetsu does not directly mention the Shömangyō-gisho or the Yuimagyōgisho, Hanayama Shinshō argues that the phrase "other sūtras" was likely meant to suggest that these two commentaries were to be included, despite a discrepancy in the number of fascicles. The Teisetsu also states that Hyeja returned to his homeland with Shōtoku's commentaries, although it does not state which he took with him. See Hanayama Shinshō, Shömangyō-gisho no Jögūosen ni kansuru kenkyü (Tokyo: Iwanami Shoten, I944), I I-33.
} 
thorship of the Sangyo-gisho are also found in the records preserved at the Shōsōin, which were published by Tokyo University's Historiographical Institute between I 90 I and I940 as the Dainihon komonjo 大日本古文書 (The Ancient Documents of Great Japan). ${ }^{14}$ These records include a number of references attributing the Sangyö-gisho to Shōtoku, often referred to as "King Jōgū", with statements describing the texts as "the composition of Prince Jōgū Shōtoku” 上宮聖徳皇子撰, “the composition of King Jōgū” 上宮王 撰, and other similar statements. ${ }^{15}$ Hanayama Shinshō believes that these earlier passages were eventually elaborated to read, "This is from the private collection of King Jōgū of the Great Land of Yamato. It is not a text from across the sea”此是大倭国上宮王私集非海彼本. Hanayama believes that this paratextual declaration of authorship was inserted into the beginning of two of the three texts between 76I and 772, not long before they were taken by the Buddhist monks Kaimyō (dates unknown) and Tokusei (dates unknown) to Tang China in $772 .{ }^{16}$

Hōryūji, the temple most closely associated with Shōtoku's exegetical activities, is likely where the study of the Sangyo-gisho began. Hanayama Shinshō argues that by the middle of the eighth century the Sangyo-gisho were likely being copied by monks at Hōryūji as an act of devotion, and possibly studied by a small group of literate monks living in the temple or having access to its textual collection, although there is little useful information about how these individuals may have actually used the texts. And it is noteworthy that until the thirteenth century, some six-hundred years after Shōtoku’s

${ }^{14}$ Joan Piggott describes the Shōsōin as an eighth century administrative archive that held over I0,000 papers and documents, which date between the 7Ios and the 760s. Many of the documents were collected from the Tödaiji Construction Agency, which, she notes, came into operation in the late 740s, while others were collected from the Shakyōjo 写経所. After the agency and its departments were disbanded in the 760 s, this collection of documents was stored in the Shōsōin, which was Emperor Shōmu's (70 I-756) royal treasure house located at Tōdaiji. Piggott adds that the records from the Shōsōin were compiled in twenty-five volumes as the Shösöin monjo, which were published between I90 I and I940 by the Shiryō hensanjo 史 料編纂所 (The Historiographical Institute of Tokyo) in the series referred to as the Dainihon komonjo 大日本古文書. See Joan Piggott, The Emergence of Japanese Kingship (Stanford: Stanford University Press, 1997), 294.

${ }^{15}$ See Hanayama, Jōgūōsen, I I-33, for a detailed discussion of these records.

${ }^{16}$ Hanayama notes that these interpolations into the Shomangyo-gisho and the Hokke-gisho differ slightly: while the Shomangyo-gisho uses 委 and 国 for "Yamato" and "country," the Hokke-gisho uses 倭 and 國. See Hanayama Shinshō, "Gyobutsu Hokkeso no sengō: shize Yamato Jōgūō shishū hikai hihon," in Indo tetsugaku no shomondai (Tokyo: Iwanami Shoten, I95 I), 397-422. 
death, in addition to this activity at Hōryūji, we can find only a handful of exegetes who studied one or more of Shōtoku's texts in any detail. Rather, memory of Shōtoku's lectures at court and texts was transmitted through non-exegetical media that include statues, mandalas, and other sorts of artwork. Indeed, the tradition of exegesis inherited by modern scholars does not emerge until the Kamakura period when the Tōdaiji polymath Gyōnen composed three detailed sub-commentaries on the Sangyo-gisho, which are still considered to be authoritative.

\section{The Sangyō-gisho in the Kamakura era}

The Kamakura period is known as a crucial period in Japanese Buddhist history in which the dominance of the Tendai and Shingon schools was challenged by new schools_-Sōtō and Rinzai Zen, Jōdoshū (Pure Land) and Jōdoshinshū (True Pure Land), and Nichiren — and by the development of offshoots of established schools, such as the Shingon Ritsu school. One of the key areas of debate among Buddhists at this time was the validity of mapp $\bar{o}$ 末 法 ("the end of the Dharma"), the predicted decline of the Buddha-Dharma that had become a popular teaching among East Asian Buddhists. Shinran and other figures from this period argued that the concomitant decline in the religious capacity of Buddhist practitioners required a new, simpler set of teachings and practices appropriate to an era of degeneration. Others, like Gyōnen, rejected the very idea that the Dharma would decline over time. This evolving understanding of the Dharma also included debates about interventions in the karmic law of cause and effect, the distinction of sudden and gradual forms of enlightenment, and the proper understanding of the Buddhist ethical system as described in the vinaya texts.

In this context, there emerged a marked increase in devotional activities directed at Shōtoku as father and first patriarch of Japanese Buddhism. Indeed, we find a diverse group of influential religious figures expressing reverence for him in artwork and poetry, exegesis and other written forms, and also by participating in various kinds of ritual and pilgrimage. Shōtoku's three texts, the Sangyo-gisho commentaries, figured prominently in this resurgence of faith as communities copied and printed, studied and remembered them in distinct ways, often doing so with not only divergent notions of Buddhist doctrine and praxis but also of what precisely constitutes the "text." For example, the first woodblock printings of the Sangyo-gisho were executed at Hōryūji, where new rituals commemorating the events described in the 
Nihonshoki and the Teisetsu were performed. Artists rendered scenes from Shōtoku's lectures and texts into various material media that include the pictorial biographies, or eden 絵伝 (“transmitting images”), found in Shinran's school. Additional textual genres became popular with varying relationships to the texts themselves: while Gyōnen produced his exhaustive exegetical studies of each of the three commentaries, there was also an increase in the composition of hymns, known as wasan, and koshiki, a textual form that combines written and performative, oral elements. Wasan and köshiki dedicated to Shōtoku and his exegetical activities were composed by Shinran, Eison, and other prominent Buddhist leaders.

The Kamakura era saw extensive activity at Hōryūji related to the Sangyōgisho: the woodblock prints noted above were carved, building projects were undertaken, and new rituals commemorating Shōtoku's lectures and texts became popular. One example is the Sangyo-gisho dangi 三経義疏談義, which began in 1227 , and was held once each week during the ninety-day period from April I 6 to July I 4. The Sangyō-gisho dangi drew upon accounts from earlier texts, such as the Höryüji shizaichō 法隆寺資材帳 and the Shisetsu ganbun 四節願文. Beginning in I 23 I, this event took place in the recently renovated Sangyōin (Hall of the Three Sūtras), which was dedicated specifically to events tied to the Sangyō-gisho. Takada Ryōshin notes from the middle of the Kamakura period, the dangi and a second ritual became the central events at Hōryūji and that they have survived into the modern era. ${ }^{17}$

With these rituals and Buddhist textual history in mind, and to better understand how the prince and his Sangyo-gisho were understood and valued, let us now turn to our four illustrative figures from the Kamakura era.

\section{Kenshin}

The first figure we examine is Kenshin, an influential Hōryūji monk who led a movement to revitalize the temple as a center of Shōtoku worship. During his tenure as head of Shōryōin, one of Hōryūjì's subtemples, he was involved in many of the activities described above. Kenshin claimed authority in matters pertaining to Shōtoku based on a secret oral transmission from his teacher Ryūsen (no dates) as well as from his family lineage that he traced back to his purported ancestor Chōshi Maru, who served as Shōtoku's chief

${ }^{17}$ Takada Ryōshin, "Shōtoku Taishi shinkō no tenkai: toku ni Hōryūji o chūshin to shite," in Shōtoku Taishi to Asuka bukkyō, ed. Tamura Enchō and Kawagishi Kōkyō (Tokyo: Yoshikawa Kōbunkan, 1985), 409. 
retainer. Some scholars paint an unflattering picture of Kenshin's possible motives and activities, claiming he may have forged texts and perpetrated other deceptions because of a keen sense of competition with Shitennōji, another temple with early ties to Shōtoku that also reemerged as a major center of Shōtoku worship in the Kamakura era.

Although he likely participated in the rituals described above, Kenshin expressed little interest in the Sangyō-gisho's ideas. For example, in the twovolume Kokon mokurokushō 古今目録抄, ${ }^{18}$ Kenshin offers much detail about the texts' dates of composition as well as his viewing and handling of Shōtoku's handwritten manuscripts, but says nothing of their content. He notes, in one instance, that as the temple's representative he took the original manuscript of the Hokke-gisho, one of the three Shōtoku commentaries, to Kyoto in I 236 for a viewing by Emperor Gohorikawa (r. I22I-I232), the Regent Kujō Michiie (I I93-I 252), and other notables near the Sōheki gate of the Imperial Palace. For his efforts, Kenshin received assistance to make repairs to Hōryūji's structures as well as a number of cultic items. In I26I, Kenshin was responsible for guiding Emperor Gosaga(r. I242-I246) on a visit to Hōryūji. In his record of their tour of the temple precincts, Kenshin claims that the emperor expressed his preference for Hōryūji over Shitennōji, and writes in the Kokon mokurokusho that he showed the emperor a copy of the Bonmōkyo 梵網經 alleged to be in Shōtoku's own hand. ${ }^{19}$ Toyoshima Yasukuni and Takatsuki Fumihiko write that this showing may have been used as a tactic to challenge the prestige and authority accruing to Shitennōji from its possession of the Shitennöji goshuinengi 四天王寺御手印縁起, a text claimed to have twenty-five imprints of Shōtoku's palms.

Hanayama Shinshō, a modern Shōtoku scholar, argues that Kenshin likely had not studied the individual works in any depth, which is surprising given Hōryūjì's close association with Shōtoku’s lectures and texts, and that Kenshin's own position and authority were tied to them. Instead, Kenshin describes regular contact with the handwritten manuscripts, imperial

${ }^{18}$ The Kokon mokurokushō is also referred to as Shötoku Taishiden kokon mokurokushō 聖 徳太子傳古今目録抄 and Shötoku Taishiden shiki 聖徳太子傳私記. The first volume was completed in I 238 and the second volume, which Kenshin had started in I230, was not completed until I 239. This work contains information from previous biographies, the secret oral transmission of the Shōtoku biographies associated with Chōshi Maru, Hōryūji's annual events, the origins of Hōryūji's buildings and inscriptions, and the histories of other temples associated with Shōtoku including Tachibanadera.

${ }^{19}$ The Bonmōkyō, or Brahma Net Sütra, is found at Ti 484 . 
showings, and receipt of financial benefits for his temple, suggesting that Shōtoku's commentaries functioned primarily as material objects that held symbolic and instrumental value, which could be used to reinforce Kenshin's own position as an authoritative interpreter and transmitter of the Shōtoku cult. This evidence thus suggests that rather than engaging the texts for their linguistic content, Kenshin offers us a clear example of a causative use.

Kenshin is also of interest because he participated in the planning and design of the Shōgō mandara 聖皇曼茶羅 with Eison (see below), produced by the artist Gyōson in I 254. This work of art offers a visual representation of Shōtoku accompanied by family members and by his past and future incarnations, such as Queen Śrīmālā and the Shingon monk Kūkai (774-835). ${ }^{20}$ It also includes an image of Shōtoku with his commentaries, which Watanabe Nobukazu describes as the beginning of a new dimension in Shōtoku worship, a sentiment that is echoed by Hanayama Shinshō and other scholars. ${ }^{21}$ Indeed, Hanayama describes its production as an important development in the transmission of the texts as "the mandala places Prince Shōtoku's commentaries in front of the Buddha's śarira [relics] thereby reproducing in visual form the connection between Shōtoku and the Sangyō-gisho." ${ }^{22}$

\section{Shinran}

The second of our four illustrative figures is Shinran (I I73-I262) who is remembered as the founder of Jōdo Shinshū 浄土真宗 (the True Pure Land school), and is known for his belief in mappo and his abandonment of the traditional precepts. ${ }^{23}$

In contrast to Kenshin, who came to the Sangyō-gisho because of a tie to a place and material objects, and whose authority was based on a religious

${ }^{20}$ After the compilation of the Nihonshoki, there emerged a growing body of stories depicting Shōtoku as sage ruler, culture hero, and father of Japanese Buddhism. Among these stories are included auspicious predictions, omens, and supernatural events, some directly related to Shōtoku's authority as a Buddhist exegete. For example, the prince was connected by rebirth and other means to central Buddhist figures including not only Śākyamuni Buddha, Queen Śrimālā (the protagonist of the Śrimālà-sütra), Maitreya (the Buddha to come in the future), Avalokiteśvara (the Bodhisattva of Compassion), Bodhidharma (the first patriarch of the Chan/Zen lineages), and the Chinese Tiantai master Huisi (5 I 5-577). These sources note that Shōtoku could speak at birth, chanted hail to the Buddha at age two, and could read Buddhist texts in Chinese at seven.

${ }^{21}$ Watanabe Nobuzaku, Shōtoku Taishi jiten (Tokyo: Kashiwa shobō, I997), 47.

${ }^{22}$ Hanayama, Jōgūōsen, 95-6.

${ }^{23}$ For a recent English language introduction to Shinran, see The Essential Shinran: $A$ Buddhist Path of True Entrusting, ed. Alfred Bloom (Bloomington: World Wisdom, 2007). 
and ancestral lineage, Shinran's path and teachings were influenced by a connection to Shōtoku established in a dream he had while engaged in a one hundred-day retreat at Rokkakudō, a Kyoto temple closely associated with the prince. The Shinran muki 親鸞夢記 notes that on the ninety-fifth day of the retreat Shōtoku appeared to Shinran in this dream, which became a transformative event that led him to the study of Pure Land Buddhism with Hōnen (I I 33-I 2 I 2). Throughout his life, Shinran retained an abiding devotion for Shōtoku as a manifestation of the bodhisattva Avalokiteśvara, which Shinran expressed in wasan, or hymns, that extolled, in a hybrid Japanese, Shōtoku's many achievements, including his lectures and commentaries. For example, in one such wasan he describes Shōtoku's lectures in language similar to that seen in the Nihonshoki:

In the presence of Empress Suiko,

[Prince Shōtoku] lectured on the Srimāalà-sütra.

When the lectures ended after three days, lotus petals rained down from the heavens. ${ }^{24}$

In another hymn that describes these lectures on the Srimālā-sütra, Shinran recounts the belief that the prince was the reincarnation of Queen Śrīmālā herself.

In ancient times as Queen [Śrīmālā], through the kindness of Saakyamuni, the Tathāgata,

[Prince Shōtoku] expounded the Śrimālā-sūtra.

Through this karmic connection,

he offered lectures on this scripture [at Japanese court] and composed a text [known as the Shomangyō-gisho on the Srimālä-sūtra].

This is indeed the beginning of the rise of the Buddha-Dharma [in this land], an [event] of great benefit to sentient beings. ${ }^{25}$

Shinran's simple and somewhat vague description of the Shömangyo-gisho, one of the three commentaries, offers essential information about what we

${ }^{24}$ Quoted in Deguchi Jōjun and Hiraoka Jōkai, Shōtoku Taishi nanto bukkyōshū (Tokyo: Tamagawa daigaku shuppanbu, I972), 240-24I.

${ }^{25}$ Quoted in ibid. 
might commonly think of as an "event": time and place, the figures involved, and a set of relationships and activities. For example, Shinran establishes Shōtoku's exegetical authority based on a previous karmic connection, recounting that in a former life the prince had been Queen Śrīmālā, the Śrimālā-sūtra's protagonist. This relationship naturally authorized Shōtoku to compose a text on the very sūtra the Queen had proclaimed before the Buddha and others in the land of Ayodhya, instructing those who had gathered in the teachings of the One Vehicle, tathaggatagarbha, and other central Mahāyāna Buddhist doctrines. Another important feature of this description is what is left unsaid. Mention is made of neither the content of Shōtoku's lectures nor the text itself. Having described these karmic connections, Shinran focuses instead on the lectures and the subsequent act of writing. This suggests that rather than any verbal content it was the event itself that inspired the composition of this hymn, and so can be described as a causative use. Indeed, depictions of the lectures and texts as such a key historical event is common still today in Wikipedia entries, television programs, YouTube clips, and comic books.

But Shinran and his community also disseminated images of Shōtoku and his texts in other media. Notable in this regard were the production of eden, painted pictorial biographies of Shōtoku that recreated in material form scenes related to his lectures and texts. These works were taken out among the laity where they were explained using etoki 絵解 (“explanation with pictures") by the school's monks to those who, even if illiterate, could learn of Shōtoku's great exegetical and other achievements. Kevin Carr notes that most of the eden were produced in Shinran's school, particularly by artists from the Takada lineage headquartered at Senjūji. The eden were designed to be taken out and shown to groups at temples or other locations, and during such showings a monk would explain the work's scenes that were generally arranged in chronological order. Carr's work suggests that it was common for Jōdo Shinshū monks working in rural areas to use these pictorial biographies to inspire devotion toward Shōtoku as a founding figure of their lineage and to convert new members. ${ }^{26}$

\footnotetext{
${ }^{26}$ See Kevin Gray Carr, "The Lives of Shōtoku: Narrative Art and Ritual in Medieval Japan” (Ph.D. diss. Princeton University, 2005), I79-I80. One representative example is a work dating to the end of the Kamakura period held in the collection of Shitennōji, which has two hangings depicting twelve scenes of Shōtoku's life. The second hanging recreates scenes associated with the belief that Shōtoku had been Queen Śīmālā in a previous life, and that his "original ground" (honji 本地), or stage on the path of the bodhisattva, was the
} 


\section{Eison}

Eison (I $20 \mathrm{I}-\mathrm{I} 290$ ) is remembered as the founder of the Shingon Ritsu sect, and was noted above because he participated in the planning and design of the Shogo mandara with Kenshin. ${ }^{27}$ Eison received broad training in Buddhism, including the study of its esoteric forms at Godaiji and the vinaya at Tōdaiji. He participated in events and rituals related to Shōtoku, including the "opening of the eyes" ceremony held at Hōryūji for a statue of Avalokiteśvara that was dedicated to Shōtoku. He was also named as the teacher charged with leading prayers to Shōtoku for the spiritual health of the nation.

Unlike Shinran, however, Eison reacted to the perceived decline of Buddhism by actively promoting the precepts as a means to re-establish "Shōtoku Buddhism," which he believed would be effective in the degenerate age of $m a p p \bar{o} .^{28}$ Eison sought to revive these rules of discipline by forging a close connection between the vinaya precepts and Shōtoku's teachings, and thereby spread his vision of a precept-based network of practitioners working actively in the community. It is recorded that he traveled through Japan giving the lay precepts to people of varied social strata, one account claiming the number of recipients surpassed 90,000. ${ }^{29}$ According to Eison's autobiography, the Kongō busshi kanjin gakushōki 金剛佛子感身学正記, he traveled to Shōtoku's mausoleum where he gave the bodhisattva precepts to a large number of people for the benefit of the nation. On another occasion, he gave the precepts to a group at Hōryūji's Eastern Compound, and, in the following year, repaired the statue of cintàmanicakra at the Shōryōin of Hōryūji. ${ }^{30}$

He also records visits to the temple's Jōgūōin, a building dedicated to the ritual remembrance of Shōtoku's lectures and texts. In these accounts,

cintāmanicakra. This work thus presents the viewer with a direct visual connection between Shōtoku as exegete and the protagonist of the very text that is the object of exegesis.

${ }^{27}$ The name Eison appears in some records with the pronunciation "Eizon." Shingon Ritsu emphasized the practice of the precepts and was affiliated with Kükai's Shingon school until I 895 when it became an independent school. For a recent work in English on Eison, see Paul Groner, "Icons and Relics in Eison's Religious Activities," in Living Images: Japanese Buddhist Icons in Context, ed. Robert H. Sharf and Elizabeth Horton Sharf (Stanford: Stanford University Press, 200I), I I 4-I 50.

${ }^{28}$ Toyoshima Yasukuni, "Eison: Taishi no honkai ni narai jakusha kyūsai o mezasu," in Shōtoku Taishi no hon: hi izuru tokoro no tenshi no tensei to mirai yogen, ed. Masuda Hidemitsu (Tokyo: Gakushū Kenkyūsha, I997), I 55.

${ }^{29}$ Ibid.

${ }^{30}$ The cintämanicakra is one among a number of manifestations of Avalokiteśvara. 
he recognizes the centrality of Hōryūji as the center of Shōtoku's exegetical work, describing the temple as the place where Shōtoku's texts have been preserved and transmitted, and where learned monks study, copy, and explicate their profound teachings. But like the two other figures he says nothing of the texts' content in his written work: neither in his autobiography nor the koshiki and wasan he composed that describe the prince's virtues and great achievements, including those related to his exegetical activities. The koshiki, which first emerged in the mid-Heian period (794-I I 85 ), are texts that are read aloud during the performance of Buddhist ceremonies, and in some cases are accompanied by music. ${ }^{31}$ Much like the wasan, they became a popular textual genre for expressing reverence for the figure of Shōtoku in the Kamakura period. And like Shinran, Eison composed wasan describing Shōtoku's lectures on the Śrimālä-sütra as an important event in the transmission of Buddhism to the archipelago. In one wasan he writes,

In the presence of Empress Suiko, [Prince Shōtoku] lectured on the Mahāyāna Śrimmālā-[sūtra],

thereby raising his fame and virtue as an exegete.

His [explication] of the profound principles [of this text] was without hindrance. ${ }^{32}$

But his view of Shōtoku as a Buddhist exegete and the value of the Sangyōgisho is apparent in other ways. As noted above, the Shomangyo-gisho and the Hokke-gisho were taken to Tang China in 772 by the Japanese Buddhist monks Kaimyō and Tokusei. Their arrival is noted by the Chinese Buddhist monk Mingkong (dates unknown) in his Shengmanjing shuyi sichao 勝䰋経

${ }^{31}$ See Abe Yasurō, "Shōtoku Taishi kōshiki," in Shōtoku Taishi jiten (Tokyo: Kashiwa shobō, I997), I26. A number of kōshiki were directed specifically at Shōtoku, including Jien's (I I 55-I 225) Kötaishi godan tandoku, which was used at Shitennōji, and is the earliest extant example. In the Kamakura period, a number of other köshiki were written and used in Buddhist temples for various functions, rituals, and so forth, related to Shōtoku. Eison's Sandanshiki, which has been transmitted at Saidaiji, is a köshiki praising Shōtoku as the patriarch of Buddhism who spread the vinaya. There is also a growing body of research on the $k o ̄ s h i k i$ written in English, including James L. Ford's "Competing with Amida: A Study and Translation of Jōkei’s Miroku Kōshiki," Monumenta Nipponica 6o, no. I (Spring 2005): 43-79. At the 2009 Annual Meeting of the American Academy of Religion, four papers were given as part of a panel titled "Points of View on the History of Köshiki: Discourse and Performativity of a Liturgical Genre" for which Ford served as respondent.

${ }^{32}$ Quoted in Deguchi and Hiraoka, Shötoku Taishi nanto bukkyōshū, 253. 
疏義私鈔, ${ }^{33}$ a commentary on the Srimālä-sūtra in which he records that the Japanese delegation presented Shōtoku's texts to Master Lingyou of Longxing monastery. Mingkong's Shengmanjing shuyi sichao is noteworthy here because its author draws not only from the thought of a number of prominent Buddhist exegetes like Kumārajīva (350-419), Zhicang (458-522), and Sengzhao (384-4I 4?), but also from Shōtoku-a prince from a small island located far across the sea from the chief Buddhist centers. ${ }^{34}$ By drawing on the ideas of the Shömangyō-gisho, Mingkong brings Shōtoku's text into the translocal Buddhist commentarial tradition by making an implied comparison: that is, this text was seen by a Buddhist exegete of China— the East Asian Buddhist motherland - to be sufficiently erudite to be used alongside the work of other great masters to illuminate the tenets of one of the Mahāyāna sūtras. The significance of this event was not lost on Eison, who came across a copy of Mingkong's text that had been brought back to the archipelago by the Japanese Tendai monk Ennin 円仁 (794-864). In a postscript to a copy of the Shengmanjing shuyi sichao that Eison presented to Hōryūji in March I256, he writes: "This [text], written by an eminent monk from the Great [Land of] Tang, adds prestige to the sublime text of Japan's [Shōtoku Taishi]." ${ }^{35}$ While Eison's activities and descriptions clearly suggest that he viewed the Sangyo-gisho as valuable, "sublime" texts, he does not seem to engage seriously their ideas.

\section{Gyōnen}

This was not the case with Gyōnen (I240-I32I), a prominent scholar of the Kegon school of Tōdaiji, who engaged in intensive study and exegesis of the texts. He studied them first with his teacher, Sōshō (I 202-I 278), and later with his own disciples. ${ }^{36}$ Gyōnen produced the first extensive subcommentaries on the Sangyō-gisho, which he wrote in classical Chinese as a

${ }^{33}$ The little that is known of its author comes from the colophon of his commentary, which states he was a disciple of Zhanran (7 I I-782), the sixth patriarch of the Tiantai school.

${ }^{34}$ Hanayama Shinshō estimates that of the approximately 26,000 characters that make up the Shomangyo-gisho, Mingkong either quotes or clearly interprets some 1,700, or about one-fifteenth of the total text. See Hanayama, Jögūosen, 66.

${ }^{35}$ Quoted in Hanayama, Jōgūōsen, 49.

${ }^{36}$ For an excellent introduction to Gyōnen's life and thought, see Mark L. Blum, The Origins and Development of Pure Land Buddhism: A Study and Translation of Gyōnen's "Jödo Hōmon Genrushō" (Oxford: Oxford University Press, 2002). Gyōnen is credited with composing some $\mathrm{I} 80$ written works totaling more than I,200 fascicles. For a listing of Gyōnen's extant written work, see “Appendix C” in Blum, 389-94. The Shömangyō-shoshōgenki 勝管 
member of the monastic elite who adopted the authoritative exegetical techniques of Chinese Buddhism. In so doing, Gyōnen created the perception among the literate, but restricted, monastic community that Shōtoku's texts were religious scriptures whose ideas made them worthy of attention and preservation.

Mark Blum notes that Gyōnen's interpretations of the Sangyō-gisho became the interpretive standard and affords him a preeminent position among Kamakura Buddhists, stating it is "probably not hyperbole to characterize him as the preeminent monk of his day." He argues that Gyōnen, together with his teachers Sōshō and Enshō (I22 I-I 277), was primarily responsible for the revival of Tōdaiji as a major Buddhist temple during the Kamakura period. ${ }^{37}$

Gyōnen's highly detailed exegesis on a vast array of topics in the prestigious kanbun reinforced his authority as an elite member of the Buddhist samgha possessing the proper training and authority to engage in textual interpretation and to pass his knowledge on to his own students. Gyōnen's influence in this regard is described by the monk Jūkyō (b. I658) as follows:

It seems that when the vinaya Master Shikan [Gyōnen] appeared, the Kegon [school] of Tōdaiji was but a trifling [presence]. The restoration and subsequent flowering [of Kegon and Tōdaiji] is due to this master. Although Sōshō was brilliant and virtuous, he did not expand the [Kegon] school. It was only after he accepted this one student Shikan that the transmission of the lamp of the Dharma [expanded]. Through his academic brilliance, [Gyōnen] raised a superior generation of monks with his efforts at lecturing, creating commentaries, and composing essays. All his students flourished [as well]. ${ }^{38}$

Gyōnen's exegetical authority was also bolstered by his broader religious authority that was a function of the prestigious position he held as head of

経疏詳玄記 is in the Dainihon bukkyō zensho 大日本佛教全書 No. 4I, 7.38, and was originally composed in 18 fascicles, I 3 of which are extant; the Yuimagyo-gisho anraki 維摩 経義疏菴羅記 is at Dainihon bukkyo zensho No. 58, I3.52 was originally 40 fascicles, I0 are extant; and the Hokkesho-eikōki 法華疏慧光記 at Dainihon bukkyō zensho No. I6, 2.2 I, was written in 60 fascicles, of which 50 are extant.

${ }^{37}$ Blum, Genrushō, 63-7.

${ }^{38}$ Quoted in ibid., 63. 
Tōdaiji, one he occupied for many years after being named his teacher's successor. Blum points out that while in this position he lectured on Kegon Buddhism at court and gave the bodhisattva precepts to Emperor Go-Uda (r. I 274-I 287), who awarded Gyōnen the title of National Teacher, the first case of a recipient being so honored during his lifetime.

Gyōnen began study of Shōtoku's texts in his twenties and continued this research until his death some six decades later, preparing the Yuimagyō-gisho anraki in the last eighteen months of his life at the emperor's request. In the colophon of that text, Gyōnen writes, "From the distant past, when I was twenty-two, until today-a period of some sixty years-I have studied the three marvelous Mahāyāna commentaries prepared by Prince [Shōtoku]."39 Indeed, Gyōnen spent much of his monastic life studying the Sangyō-gisho as part of what Brian Stock describes as a "textual community," ${ }^{40}$ which he uses to highlight those communities that function not simply as an interpretive group but also as a social body. Elaborating Stock's concept of the "textual community," Anne Blackburn describes such a community as a "group of individuals who think of themselves to at least some degree as a collective, who understand the world and their appropriate place within it in terms significantly influenced by their encounter with a shared set of written texts or oral teachings based on written texts, and who grant special social status to literate interpreters of authoritative written texts." ${ }^{11}$ This is an apt description of Gyōnen's engagement with the Sangyo-gisho as he defined himself within Tōdaiji and the broader Buddhist community by his ability to interpret these texts, and came to be seen as a "custodian of authoritative interpretation." 42 He signed his name in a number of works with variations on the epithet, "Scholar of Prince Shōtoku's Three Commentaries": for example, he signs his name in one of his studies as "Gyōnen, Śramaña of the Kegon and Vinaya [Schools], of the Vajra and Joyous Pure [Land], Scholar of [Shōtoku's] Three Commentaries." ${ }^{43}$ But the value Gyōnen ascribed to the Sangyō-gisho can be

${ }^{39}$ Quoted in Hanayama, Jōgūosen, Iо I.

${ }^{40}$ Stock, Listening for the Text, I 50.

${ }^{41}$ Anne Blackburn, Buddhist Learning and Textual Practice in Eighteenth-Century Lankan Monastic Culture (Princeton: Princeton University Press, 200I), I 2.

42 This phrase of Martin Irvine appears in Blackburn, I 49.

${ }^{43}$ Quoted in Hanayama, Jögūosen, Iо I. Gyōnen's exegesis of the Sangyō-gisho is also noteworthy because he adopts a format in which he takes on the voice of the prince. That is, he uses a question and answer format in which Shōtoku, usually referred to as "author of the commentary," is asked a question, after which his answer is provided by Gyōnen as spokesperson. Gyōnen's teacher Sōshō is believed to have written a text on the Shömane 勝鬘會 using 
seen not only in the great effort he poured into his exegesis, but also in the concern he expressed over the great loss that would occur if these texts were to go out of circulation. He recorded his desire to transmit the Shömangyō-gisho in a more readily accessible form to his disciple Zenmyō, by adding markings to a copy of a Kamakura print to aid his disciple in reading the text. Gyōnen states that he gave this marked-up text to his disciple so "it will be possible to transmit the three commentaries produced by Prince [Shōtoku] and not waste his great effort." 44

In this way, Gyōnen's exegesis represents a key developmental stage in the transmission of the Sangyo-gisho, as it marks the three texts to be worthy of extended study in their own right, a tradition of study that has been inherited by modern scholars. He is also an important figure in this tradition because he clarified the texts' position within the body of East Asian commentaries on the Śrimālä-sūtra, the Lotus-sütra, and the Vimalakirtinirdeśa by identifying their intellectual lineage, recovering the texts' original forms, and explaining their profound and timeless meaning. His work on these matters is often cited by modern scholars.

\section{Conclusion: a comparison of Shinran and Gyōnen}

Each of these contemporaries comes to Shōtoku's texts from distinct Buddhist communities, and each uses and values them in different ways and for different purposes. ${ }^{45}$ While their individual uses of the texts are not mutually exclusive-for example, Kenshin may have actually studied them-they do suggest the limits of scholarship that focuses on the "text" solely as an unchanging body of ideas. Jerome Bruner, drawing on the thought of Wolfgang Iser, describes these individual notions of a particular text as a "virtual text," which is a useful phrase for highlighting the variability we see in these four figures. Bruner states that when an individual reads a text, while "the actual text is unchanged, the virtual text (to paraphrase Iser) changes almost mo-

this format, and Gyōnen used it in other works including the Hasshū kōyō 八宗綱要 (Dainihon bukkyō zensho No. I02, 29.1 I) and the Sangoku buppō denzū engi 三国仏法傳通縁起 (Dainihon bukkyō zensho No. 467, 62.7). But Gyōnen reinforced his interpretive authority in other ways: for example, by signing his name with variations on the epithet "Scholar of Prince Shōtoku's Three Commentaries," he makes at least an implicit claim that he possessed the requisite training and understanding to interpret and transmit them.

${ }^{44}$ Hanayama, Jögūosen, I I.

45 There are other interesting figures from this period, such as Nichiren and Myōe (I 173-I 232), who engaged the Sangyö-gisho and are also deserving of study. 
ment to moment in the act of reading." ${ }^{46}$ And while Bruner's description of the virtual text is applied to the act of reading a work from beginning to end, we have seen in the material described above that Buddhists, including those connected to the Sangyo-gisho, often "read" texts in other ways. These too can be described as a type of "virtual text." In the case of the Sangyo-gisho, some, like Gyōnen and many modern scholars, have clearly engaged in what Paul Griffiths calls "religious reading." This type of reading is deliberative, slow, and repetitive, and suggests a mode of engaging a religious text in which a reader seeks not simply to extract pieces of information, which he calls "consumerist reading," but also desires to be transformed in the process. ${ }^{47}$ But the varied uses of Kenshin, Shinran, and Eison suggest just a few of the other possibilities for conceiving, or "reading," these texts, and understanding their author.

Gyōnen and Shinran offer an illuminating comparison with which to conclude since each occupied distinct positions within the Buddhist community, subscribed to different types of teachings and practices, and seems to have come to the Sangyo-gisho from varied directions. For example, in contrast to Gyōnen, Shinran accepted mappō, the predicted decline of the Dharma, and Shinran led a religious movement that threatened established power, while Gyōnen held high positions in the Tōdaiji hierarchy, one of the most powerful temples in the land. Indeed, Shinran was, with his teacher Hōnen, exiled for their teachings: the former to Echigo (modern day Niigata Prefecture) and the latter to Tosa (modern day Kōchi Prefecture). Shinran is also well-known for abandoning the very precepts that Gyōnen himself sought to revivify.

But we can also distinguish their individual conceptions of the texts: unlike Shinran, who simply and poetically describes the "textual event" in a hybrid Japanese, Gyōnen writes in classical Chinese as both a Buddhist exegete and historian. And in contrast to Shinran who describes Shōtoku's exegetical authority via reincarnation tied directly to India, Gyōnen sees it emerging from an unbroken textual transmission among the "three lands" of India, China, and Japan. For him, Shōtoku's locally produced texts were crucial to proper Buddhist transmission and were legitimized by their full participation in the intellectual lineage of the Chinese master Fayun (467-529)

${ }^{46}$ Jerome Bruner, Actual Minds, Possible Worlds (Cambridge: Harvard University Press, I987), 7 .

${ }^{47}$ Paul Griffiths, Religious Reading: The Place of Reading in the Practice of Religion (New York: Oxford University Press, 1999), ix. 
and the broader translocal Chinese thought world. Gyōnen writes, "The religious teachings that have been explicated by King Jōgū [in the Hokke-gisho] rely on the model text of Master Fayun [of the Sanlun-Chengshi school]. The Yuimagyō-gisho and Shömangyö-gisho also were written based upon the teachings of [Master] Fayun. In this way, the origin [of Shōtoku's texts] was established on principles taught by [this Chinese master]." 48

Modern studies of the Sangyo-gisho have viewed the concerns elucidated by Gyōnen as proper subjects for serious scholarship, including the texts' original form and meaning, their intellectual lineage, and their "principles" or doctrines. And much like Gyōnen, modern scholars have become authorities by mastering Buddhism's traditional philological methods requiring intensive doctrinal, historical, and linguistic study. ${ }^{49}$ In this tradition, Buddhist texts are viewed as timeless vehicles that transmit a fixed body of ideas-once recorded in a material form, their meaning becomes available to those who possess the proper tools and training. But by privileging the exegetical and erudite as the only serious way to understand the Sangyo-gisho, scholars have failed to investigate how other sorts of communities have come into contact with and understood the Sangyō-gisho. Unlike Gyōnen's “textual community" centered at Tōdaiji, these might be described as "non-exegetical" communities, whose uses of the Sangyo-gisho are primarily or exclusively causative. ${ }^{50}$ This tendency among modern scholars is especially striking given that the texts' symbolic value was recognized long before Gyōnen produced

${ }^{48}$ Quoted in Ippei Okamoto, "Gyōnen no Shōtoku Taishi shinkō," Indogaku bukkyōgaku kenkyü 47, no. 2 (1999): 743. The Chengshi school was viewed by Chinese Buddhists as a branch of the Sanlun school.

49 Indeed, there is a growing body of scholarship critiquing the field's so-called "traditional paradigm," which Frank Reynolds describes as one that "places a strong emphasis on the study of texts and the intention of their presumed author; [and] on the search for origins... Methodologically this traditional paradigm privileges a language-centered philological approach, gives little attention to the historical context and usage of texts, emphasizes the production of authoritative critical editions and translations, and tends toward a positivistic view of historical methods and historical facts." See Frank Reynolds, "Coming of Age: Buddhist Studies in the United States from 1972 to 1997," Journal of the International Association of Buddhist Studies 22, no. 2 (I999): 462.

${ }^{50}$ Gregory Schopen has been a particularly vocal critic of these traditional methods of textual study, asserting that scholars have helped to create and perpetuate a distorted view of early forms of Indian Buddhism by uncritically accepting images of Buddhist communities that appear in a textual corpus produced by monastic elites with a vested interest in portraying their institutions and activities in a positive light. He argues, moreover, since Buddhist texts can be difficult to date, can undergo multiple edits, and are often meant to inculcate particular ideals among their readers, they generally serve as inherently unreliable historical 
his detailed sub-commentaries, and that it has been common for Buddhist communities to use texts for such causative purposes, with little or no connection to their linguistic content. But if we "listen" attentively for the "text" in these multiple forms and among these distinct voices, an alternative view emerges, one that does not reduce the Sangyo-gisho to a singular, discrete event of meaning making. Rather, our focus shifts from recovering the original meaning and value of these texts to analyzing how they have, at different times and among varied communities, been received and used, transmitted and valued.

witnesses to lived Buddhism; that is, "textuality overrides actuality" (Schopen, Bones, Stones, and Buddhist Monks, 7). By drawing instead upon epigraphic and archaeological evidence, Schopen has challenged key assumptions regarding the nature of early Indian Mahāyāna Buddhism and the development of its textual traditions. For a useful introduction to Schopen's views, see Bones, Stones, and Buddhist Monks: Collected Papers on the Archaeology, Epigraphy, and Texts of Monastic Buddhism in India (Honolulu: University of Hawai'i Press, 1997). See also "The phrase 'sa prthivīpradeśas' caityabhüto bhavet' in the Vajracchedikä: Notes on the cult of the book in Mahāyāna," Indo-Iranian Journal I7, nos. 3/4 (I975): I47-I8I. This article is reprinted in Figments and Fragments of Mahāyāna Buddhism in India: More Collected Papers (Honolulu: University of Hawai'i Press, 2005), 25-62. Schopen's own conclusions have not been uncritically accepted, however. For example, David Drewes argues that his views regarding the timing and nature of Mahāyāna Buddhism's unique development of a "cult of the book" rely on tenuous evidence. Drewes writes, "Although Mahāyānists certainly venerated texts in written form, the practice seems unlikely to have played an especially important role in the movement. Rather than being distinctly or even originally Mahāyāna, the practice seems to have been pan-Buddhist, or even pan-Indian, from an early date" (Drewes, "Early Indian Mahāyāna Buddhism I," 60). Drewes calls for a basic shift in how we study Buddhism's vast textual corpus, arguing that because Westerners have generally imagined the true teachings of Buddhism to be found in its meditative practices and philosophical treatises, they have generally ignored other common textual practices involving memorization, recitation, preaching, copying, and worshipping Buddhist texts. See David Drewes, "Revisiting the phrase 'sa prthivippradeśaś caityabhūto bhavet' and the Mahāyāna cult of the book," IndoIranian Journal 50, no. 2 (2007): IOI-I 43, "Early Indian Mahāyāna Buddhism I: Recent Scholarship," Religion Compass 4, no. 2 (2010): 55-65, "Early Indian Mahāyāna Buddhism II: Recent Scholarship," Religion Compass 4, no. 2 (2010): 66-74. 